\title{
Fabricating Pinhole-Free YSZ Sub-Microthin Films by Magnetron Sputtering for Micro-SOFCs
}

\author{
T. Hill and H. Huang \\ Department of Mechanical and Materials Engineering, Wright State University, Dayton, OH 45435, USA \\ Correspondence should be addressed to H. Huang, hong.huang@wright.edu
}

Received 2 September 2010; Revised 19 October 2010; Accepted 2 November 2010

Academic Editor: Boniface Kokoh

Copyright (๑) 2011 T. Hill and H. Huang. This is an open access article distributed under the Creative Commons Attribution License, which permits unrestricted use, distribution, and reproduction in any medium, provided the original work is properly cited.

\begin{abstract}
Submicron thin yttria stabilized zirconia (YSZ) films were prepared on a variety of substrates with different surface morphologies by magnetron sputtering followed by thermal oxidation. Pinholes were observed in the films deposited on nanoporous alumina substrates. Initial dense Y/Zr films developed nanocracks after thermal oxidation on smooth Si wafer substrates. At optimal sputtering and oxidation conditions, smooth and crack/pore-free films were achieved on Si wafer substrates. The thin YSZ films exhibited fully ionic conduction with ionic conductivities, and activation energy corroborated well with the values from commercial YSZ plates. The thin YSZ films can be utilized in Solid Oxide Fuel Cells (SOFCs) for intermediate temperature operations.
\end{abstract}

\section{Introduction}

Yttria stabilized zirconia (YSZ), an oxide ion conductor, has been the primary electrolyte in Solid Oxide Fuel Cells (SOFCs) because of its mechanical strength and chemical stability. Practically, the area-specific resistance (ASR) from the YSZ electrolyte needs to be less than $0.1 \mathrm{ohm} \cdot \mathrm{cm}^{2}$ to ensure high-energy efficiency. However, the minimum thickness of YSZ that can be mass produced for SOFCs is in the range of tens of micrometers. The large thickness, low oxideion conductivity, and high conduction activation energy (around $1.0 \mathrm{eV}$ ) result in large ASR of the YSZ electrolyte at low temperatures. As a consequence, traditional YSZbased SOFCs require high operating temperatures (above $800^{\circ} \mathrm{C}$ ) which limit the choice of sealing materials and create numerous problems such as corrosion and performance degradation. Lowering SOFCs operating temperature is in highly demand, particularly for potential applications in transportation and portable electronics [1-4]. When the reaction kinetics at both cathode and anode are facile, reducing the YSZ thickness is critical. For instance, the decrease of the YSZ thickness from $10 \mu \mathrm{m}$ to $400 \mathrm{~nm}$ can reduce the operating temperature from $800^{\circ} \mathrm{C}$ to $450^{\circ} \mathrm{C}$.
Recently, there is growing interest to fabricate state-of-theart electrolyte sub-microthin films for SOFCs capable of operating at intermediate temperatures [5-9].

The major challenges to successfully employ submicrothin electrolytes are to ensure the films fully dense and pinhole-free. Various morphological substrates and deposition approaches have been investigated to fabricate YSZ thin films. The minimum thickness YSZ films directly deposited on porous Ni-YSZ anode was around $2-5$ micrometer, restricted by the microsize pores in the anode substrate $[10$, 11]. Dense YSZ thin films were constantly achieved by using pulse laser deposition (PLD) and atomic layer deposition (ALD) on dense smooth substrates, like $\mathrm{Si}$ or $\mathrm{Al}_{2} \mathrm{O}_{3}$ wafer $[8,12,13]$. However, PLD can hardly produce homogeneous thin films in large area, and ALD is relatively expensive from the practical point of view.

Sputtering is one of the widely used and relatively low cost thin film deposition approaches. By adjusting deposition parameters, for example, gas pressure, deposition power, substrate temperature, and sputtering time, different morphologies including fully dense and highly porous films can be achieved [14]. Park deposited YSZ thin films onto anodized nanoporous alumina substrates followed by oxidation at temperature of $500^{\circ} \mathrm{C}$ [15]. However, the measured 
conductivity values were two-order magnitude lower than the values from commercial YSZ plate. Additionally, the minimum thickness of YSZ films in the SOFC configuration was $670 \mathrm{~nm}$ to achieve open circuit voltage (OCV) of $0.83 \mathrm{~V}$, lower than the theoretical value. The low OCV value indicated the existence of gas leakage through the thin film. Recently, Huang et al. [7] demonstrated a working ultrathin SOFCs, which consisted of the $50 \mathrm{~nm}$ thick YSZ films directly deposited by radio frequency (RF) sputtering on $\mathrm{Si}$ substrate. Huang et al. also reported increased conductivities in ultrathin gadolinia-doped ceria deposited by magnetron sputtering followed by thermal oxidation [16]. RF-sputtering renders directly deposit oxide films from the corresponding ceramic targets. Magnetron sputtering, however, requires an electronic conducting target which can only deposit metallic films directly. Thermal oxidation process is necessary to obtain oxide films. The disadvantages of RF-sputtering relative to magnetron-sputter include (1) the deposition rate is very low, (2) metal-rich films tend to form, (3) ceramic targets (the brittle and poor thermal conducting) are susceptible to thermal stress crack at high power, and (4) the RF power supplies are expensive. Hence, RF-sputtering, though common in laboratory research, has seen limited industrial application [14].

Presented in this report is a series comparison of morphological results of YSZ thin films deposited via DC magnetron sputtering. Three different substrates, that are, nanoporous alumina, nonporous rough-surfaced alumina plate, and nonporous smooth-surfaced Silicon wafer, were selected. Anodized nanoporous alumina substrate, having vertical channels completely through the membrane, may lead to its functions as both the gas flow channel and the structural supporter for micro SOFCs [15]. Nonporous substrates like alumina or silicon wafer can serve as microfuel cell supporter after back etching [7-9]. The influences of the substrates and processing conditions on the quality of YSZ thin films were discussed. Ionic conductivities of the thin films deposited on nonporous alumina substrate were analyzed based on electrochemical impedance spectroscopy.

\section{Experimental Aspects}

2.1. Thin Film Preparation and Morphology Imaging. The YSZ thin films were deposited by using the DC magnetron sputtering approach. A 16:84 Y-Zralloy plate which had a purity of $99.9 \%$ was used as a DC sputtering target (Kurt J. Lesker). The target was $5.08 \mathrm{~cm}$ (2 inch) in diameter and $0.32 \mathrm{~cm}(0.125$ inch $)$ in thickness. The distance between the target and the substrate was $10 \mathrm{~cm}$. The substrate materials selected for film deposition were anodized nanoporous alumina (Whatman), nonporous polycrystalline alumina plate (Kyocera), and nonporous Silicon wafer (Si). On the Si wafer, a $500 \mathrm{~nm}$ thick silicon nitride layer was grown by chemical vapor deposition prior to YSZ thin film deposition. This silicon nitride layer served two functions: (i) a buffer layer to prevent Si diffusion into YSZ thin films during heat treatment and (ii) a blocking layer for wet-etching Si during fabrication of micro-SOFCs by MEMS technology [7-9].
The DC sputtering was performed at room temperature, and sputtering power was set at 200 watts. Argon pressure and deposition time were varied to control the porosities and thicknesses of the films. To achieve the "dense $\mathrm{Y} / \mathrm{Zr}$ film" noted in this paper, $0.5 \mathrm{~Pa}$ argon pressure was used, and the deposition rate was estimated at $5 \mathrm{~nm} / \mathrm{s}$. To achieve the "porous Y/Zr films", argon pressure was adjusted to $2 \mathrm{~Pa}$ and the deposition rate decreased to $2 \mathrm{~nm} / \mathrm{s}$. The $\mathrm{Y} / \mathrm{Zr}$ films were then oxidized in a box furnace at the setting temperatures for 5 hours in air to form oxide film (referred to as YSZ films in this paper). Traditional micrometer thick YSZ plates were usually manufactured at high temperatures in the range of $1000-1400^{\circ} \mathrm{C}$. It is necessary, however, to keep the processing temperatures of YSZ thin films low in consideration of the chemical compatibility with the substrate and control of stresses induced by thermal expansion. In this research, two oxidation temperatures, that are $800^{\circ} \mathrm{C}$ and $1200^{\circ} \mathrm{C}$, were selected to compare the ionic conduction performances of the YSZ thin films. The surface and cross-section morphologies of the thin films before and after thermal oxidation were imaged using scanning electron microscope (FEI and JEOL).

2.2. Electrochemical Characterization. To perform conductivity characterizations, a $200 \mathrm{~nm}$ thick platinum layer was patterned on top of the $\mathrm{Y} / \mathrm{Zr}$ and/or the YSZ films on dense alumina substrate. The dense Pt electrode patterns were deposited via DC-sputtering at $1 \mathrm{~Pa}, 100 \mathrm{~W}$, and room temperature with the aid of a shadow mask. The Pt electrode pads are $0.5 \mathrm{~cm}$ long and $0.4 \mathrm{~cm}$ wide, and the spacing between two electrode pads was $0.2 \mathrm{~cm}$. For impedance measurements, the deposited films with Pt electrode patterns were connected through $\mathrm{Pt}$ wires to an electrochemical analysis system (Gamry) and placed in a temperature controlled tube furnace (Carbolite). Electrochemical impedance spectra (EIS) were recorded in air at $50^{\circ} \mathrm{C}$ intervals with the selected temperature range after thermal equilibrium was achieved (2-3 hours). The AC amplitude was $50 \mathrm{mV}$, and the frequency was swept between $1 \mathrm{~Hz}$ and $0.5 \mathrm{MHz}$. The EIS results were analyzed using Z-plot software based on complex nonlinear least squares fitting [17].

\section{Results and Discussion}

3.1. Influences of Substrates on Morphologies of the AsDeposited $\mathrm{Y} / \mathrm{Zr}$ Thin Films. Figure 1 showed a series of SEM images comparing the three bare substrates and the top and cross-sectional view of the as-sputtered $\mathrm{Y} / \mathrm{Zr}$ thin films on these substrates. All the films were deposited at the same parameters, that are room temperature, $200 \mathrm{~W}, 0.5 \mathrm{~Pa}$, and $80 \mathrm{~s}$. The atomic ratio of $\mathrm{Y} / \mathrm{Zr}$ in the as-deposited and later thermally oxidized thin films were confirmed to be 0.19 on average based on EDX analyses equipped in SEM microscope, which was consistent with the target composition (16/84). The oxygen over metal (sum of Y and $\mathrm{Zr}$ ) ratio is in the range of 1.90 to 1.95 , which is close to the theoretical value in $8 \mathrm{~mol} \%$ Yttria stabilized zirconia; the compositional formulae of which is $\mathrm{Y}_{0.16} \mathrm{Zr}_{0.84} \mathrm{O}_{1.92}$. 


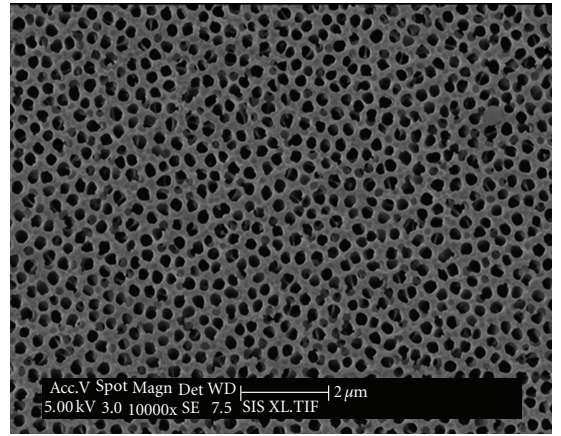

(a1)

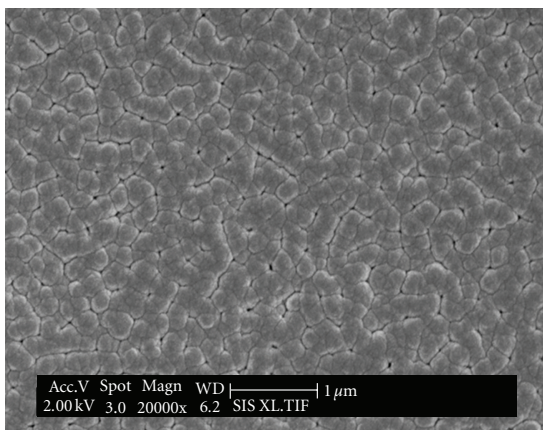

(a2)

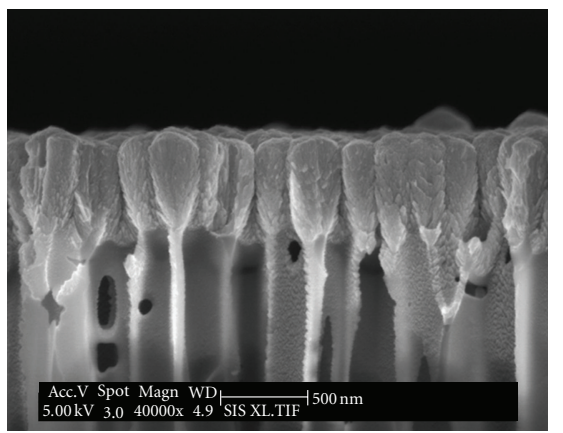

(a3)

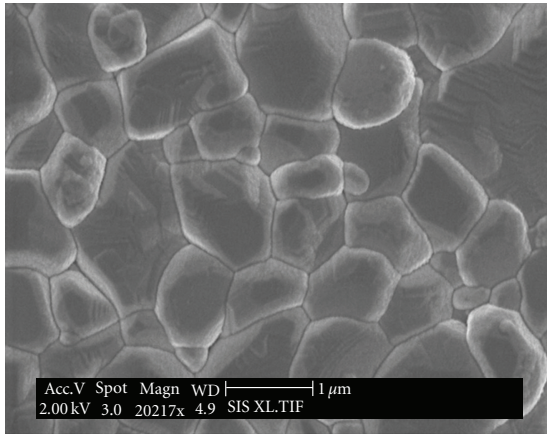

(b1)

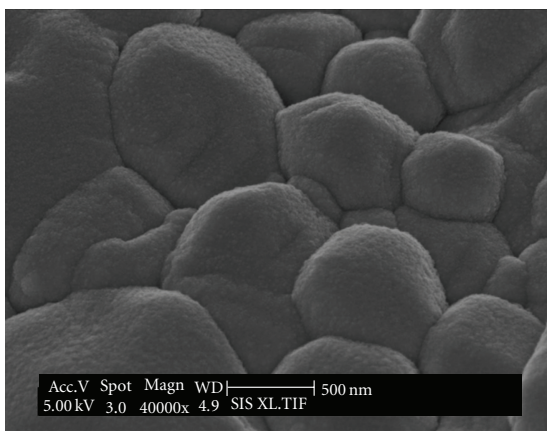

(b2)

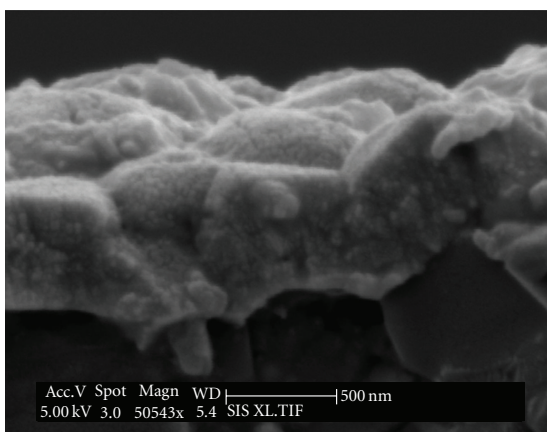

(b3)

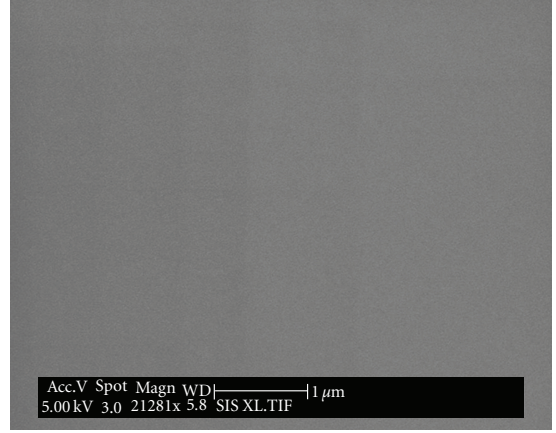

$(\mathrm{c} 1)$

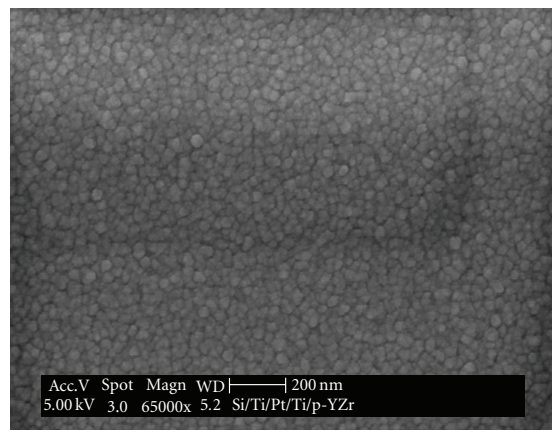

(c2)

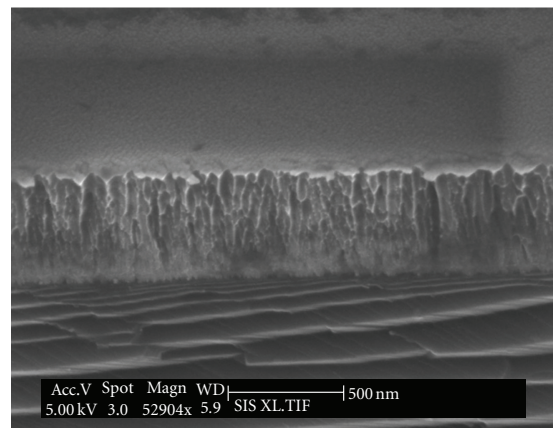

(c3)

Figure 1: SEM images of the top-view substrates (a1) nanoporous anodized alumina, (b1) nonporous alumina plate, (c1) smooth single crystal Si wafer with $500 \mathrm{~nm}$ thick silicon nitride layer, top-view (a2, b2, c2) and cross-view (a3, b3, c3) of the as-deposit Y/Zr films. The deposition conditions are $200 \mathrm{~W}, 0.5 \mathrm{~Pa}$, and $80 \mathrm{~s}$ at room temperature.

As can be seen from Figure 1(a1), the porous anodized alumina substrate had an average pore diameter of $200 \mathrm{~nm}$ with the wall thickness in the range of $20 \mathrm{~nm}$ to $50 \mathrm{~nm}$. Figure 1(a2) was the top-view image of Y/Zr films deposited on the porous substrate. The image revealed apparent pinholes throughout the imaging area. Figure 1(a3) showed the cross-section image of the $\mathrm{Y} / \mathrm{Zr}$ film, which has an average thickness of $370 \mathrm{~nm}$ under the deposition condition. In the process of sputtering, the initial $\mathrm{Y} / \mathrm{Zr}$ particles were only deposited on the narrow walls of the substrate's pores. These particles became seeds for the following $\mathrm{Y} / \mathrm{Zr}$ particles such that thin films developed and grew on channels in three dimensions. As a result, the pores gradually shrank into the tulip-shaped films that were observed in Figure 1(a3). However, the pores yet entirely disappeared in the $370 \mathrm{~nm}$ thick film. Later a microfuel cell consisting of $100 \mathrm{~nm}$ thick $\mathrm{Pt}, 370 \mathrm{~nm}$ YSZ, and $100 \mathrm{~nm}$ thick Platinum, was fabricated on the anodized alumina substrate via DC sputtering followed by oxidation at $800^{\circ} \mathrm{C}$ for 5 hours. The fuel cell was then subjected to performance evaluation by using hydrogen as a fuel and air as the oxidant. Only $0.2 \mathrm{~V}$ was obtained at the open circuit condition. The low open circuit voltage (OCV) resulted from the existing pinholes in the YSZ electrolyte thin film leading to significant gas cross-over. The morphological observations and OCV results suggested that $370 \mathrm{~nm}$ thin YSZ electrolyte films grown on the porous alumina substrates were unacceptably for micro-SOFCs.

Following investigations, therefore, were focused on YSZ thin films deposited on nonporous substrates, that are polycrystalline alumina plate and Si wafer. The nonporous 


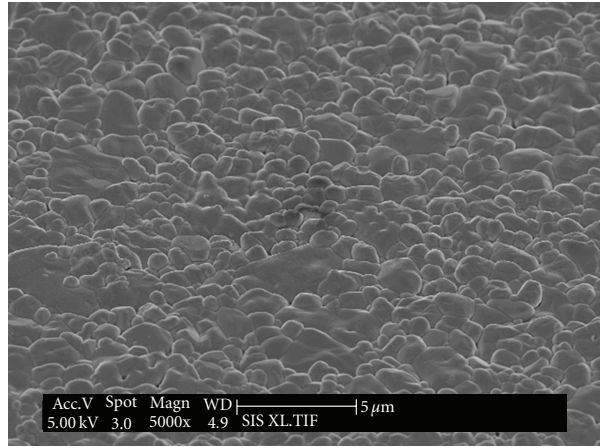

(a1)

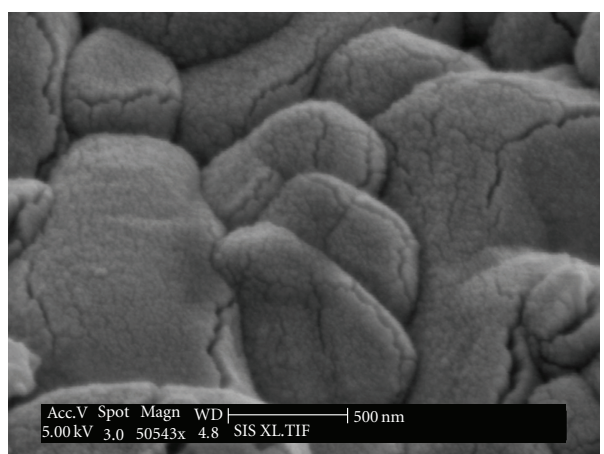

(a2)

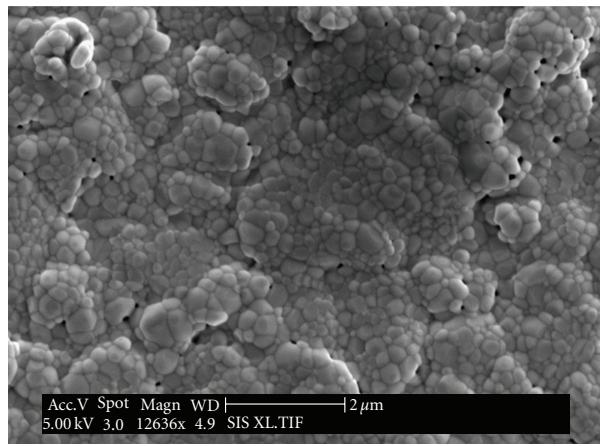

(a3)

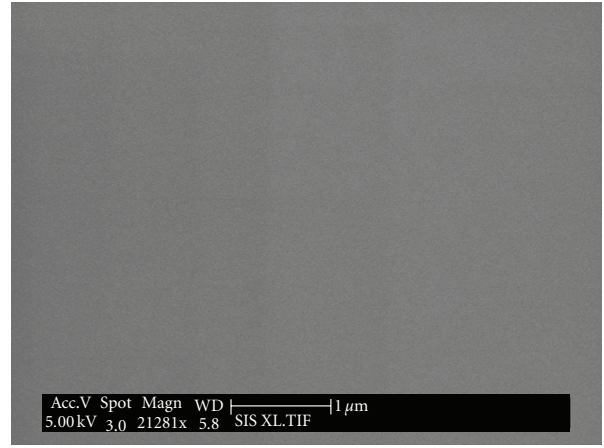

(b1)

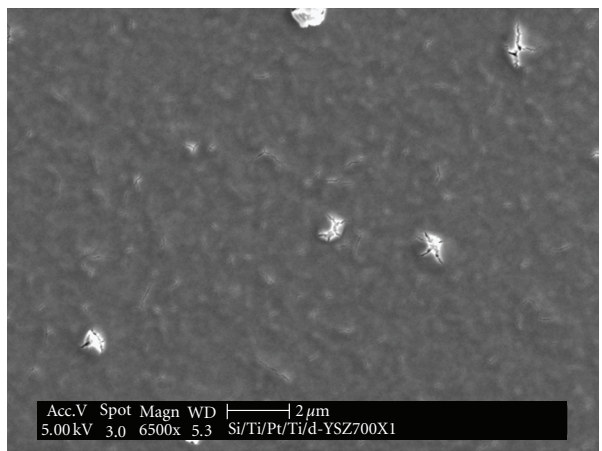

(b2)

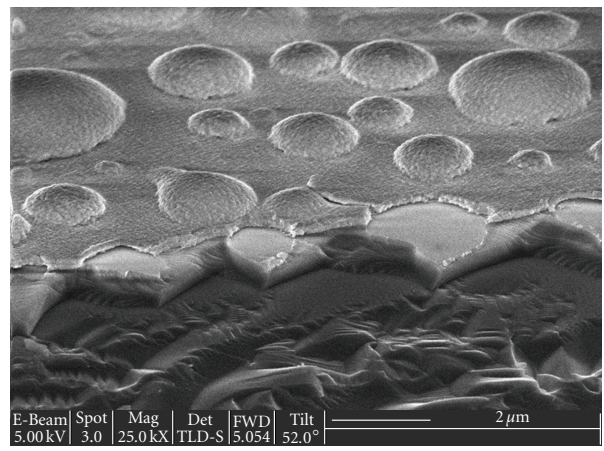

(b3)

FIgURE 2: SEM images of different thin films deposited on dense polycrystalline alumina plate (a series) and on silicon wafer (b series). (a1, b1) as-sputtered, (a2, b2) annealed at $800^{\circ} \mathrm{C}$, and (a3, b3) annealed at $1200^{\circ} \mathrm{C}$.

alumina plate was made up of alumina grains in the size range of $500 \mathrm{~nm}$ to $1 \mu \mathrm{m}$, as can be seen in Figure 1(b1). The as-deposited $\mathrm{Y} / \mathrm{Zr}$ film fully covered the alumina surface with the same morphological pattern as the substrate (Figure 1(b2)). No pinholes were visible but the film was grainy and uneven. The average grain size of $\mathrm{Y} / \mathrm{Zr}$ was approximately $20 \mathrm{~nm}$. The thickness of the $\mathrm{Y} / \mathrm{Zr}$ film was in the range of $370-380 \mathrm{~nm}$ (Figure $1(\mathrm{~b} 3)$ ). On the Si wafer, the deposited Y/Zr film was much more smooth and homogenous (Figures $1(\mathrm{c} 1)-1(\mathrm{c} 3)$ ) in comparison to the films on polycrystalline alumina substrate. No pinholes were visible from top view and cross-section view. The thickness of the film was $380 \mathrm{~nm}$. Clearly, the deposition rate was close to $5 \mathrm{~nm} / \mathrm{s}$ at the experimental setting conditions, independent of the substrate morphologies.
3.2. Influence of Oxidation Temperatures on Film Morphology. Oxidation temperatures had profound impacts on the film morphologies of YSZ films. SEM images of the thin films before and after thermally annealing at $800^{\circ} \mathrm{C}$ and $1200^{\circ} \mathrm{C}$ were compared in Figure 2. The films were deposited on the nonporous alumina substrate and on silicon wafer. At oxidation temperature of $800^{\circ} \mathrm{C}$, nanocracks were generated in the film (Figure 2(a2)) from the dense and pinhole/crackfree as-sputtered films (Figure 2(a1)). After being oxidized at $1200^{\circ} \mathrm{C}$ for $5 \mathrm{hrs}$, the grain size increased around ten times, that is, from $10-30 \mathrm{~nm}$ to $100-300 \mathrm{~nm}$. Simultaneously, nanopinholes with average diameter of $100 \mathrm{~nm}$ were generated in films on alumina substrate, especially in the vicinity of grain boundary regions (Figure 2(a3)). Similar phenomena were observed in the films made on Si wafer 


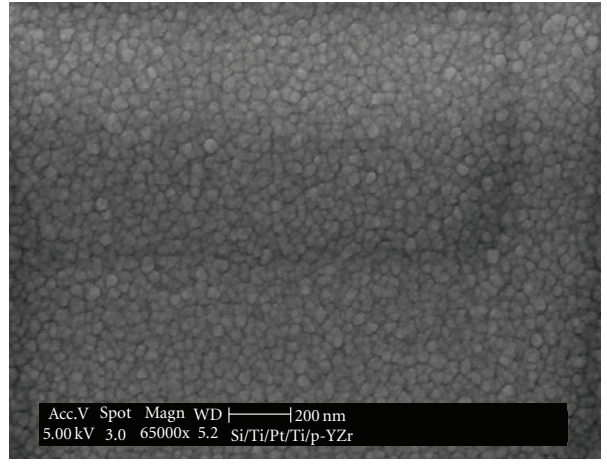

(a1)

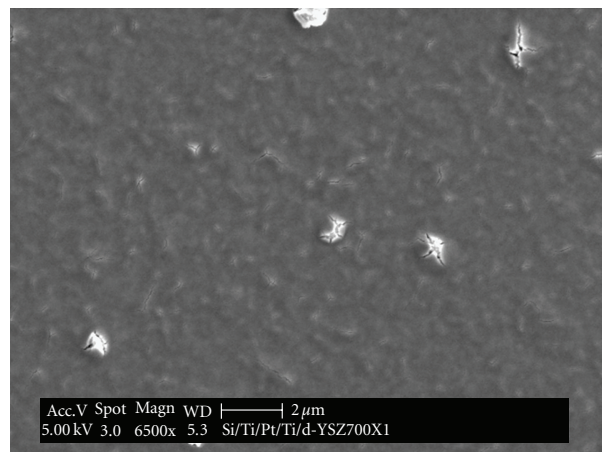

(a2)

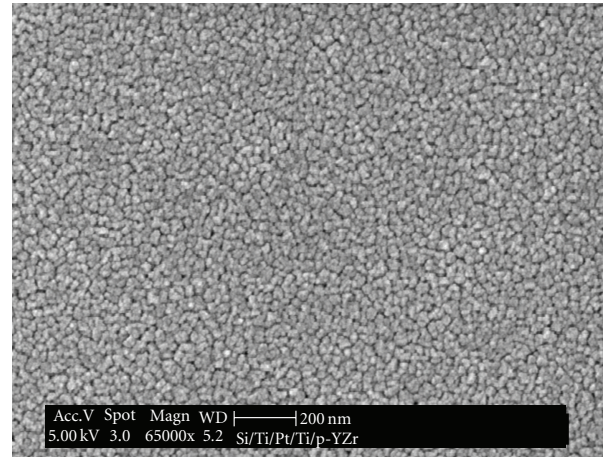

(b1)

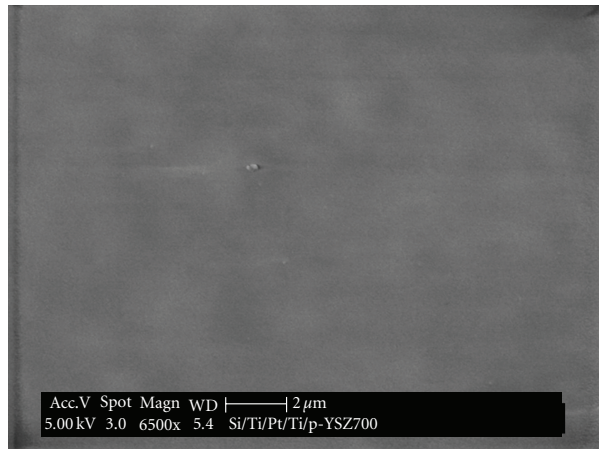

(b2)

FIgure 3: SEM images of (a1) dense Y/Zr film deposited at $0.5 \mathrm{~Pa}$; (b1) less dense Y/Zr thin films deposited at 2 Pa; (a2) YSZ thin films oxidized from (a); (b2) YSZ thin films oxidized from (b). The substrate is Si wafer. Oxidation condition is $800^{\circ} \mathrm{C}$ for $5 \mathrm{hrs}$.

films. Compared to those on polycrystalline alumina plate, cracking and pore generation on Si wafer were more severe because the films were denser prior to oxidation (see Figures 2(b2) and 2(b3)). Many spherical bubbles were generated and detached from Si surface after $1200^{\circ} \mathrm{C}$ oxidation. The observed dramatic morphological changes were attributed to the expansion of closed packed crystal structure of the pure metals to the fluorite crystal structure of zirconium oxide as a consequence of oxidation.

These observations led to experiments on developing "as deposited" Y/Zr thin films with less density in Si wafer substrate to accommodate volume expansion after oxidation. A series of experiments were conducted to tailor the density of the Y/Zr films via adjusting sputtering pressure. It was found that increasing sputtering pressures increased the porosity of the "as sputtered" films. Figure 3 showed SEM images of the as-deposited Y/Zr films as well as the oxidized YSZ thin films. Apparently, Y/Zr thin film deposited at $2 \mathrm{~Pa}$ was more porous (Figure 3(b1)) than that deposited at $0.5 \mathrm{~Pa}$. After oxidation at $800^{\circ} \mathrm{C}$ for $5 \mathrm{hrs}$, pinhole free as well as crack-free YSZ thin films were achieved on smooth Si wafer (Figure 3(b2)).

3.3. Ionic Conductivities of Oxidized YSZ Thin Films. The conductivities were derived from electrochemical impedance spectra obtained in the planar configuration, as sketched in Figure 4(a). According to electrochemical impedance theory [17], the highest frequency (hf) impedance arcs in
Nyquist plot (imaginary-part impedance $Z^{\prime \prime}$ versus real-part impedance $Z^{\prime}$ obtained from frequency sweep) are associated with conduction processes in thin films between the two platinum electrodes. In YSZ polycrystalline specimens, oxide ions can conduct in bulk grains and grain boundaries. Correspondingly, there will be two arcs in the frequency range of a few to hundreds of $\mathrm{kHz}$ in Nyquist plot. A circuit, as shown in Figure 4(b), is equivalent to the two conducting processes, which will not be discussed extensively here. Small differences in characteristic frequencies for bulk and grain boundary conduction may result in overlap of the two arcs. Figure 4(c) exhibited a typical Nyquist plot recorded at $350^{\circ} \mathrm{C}$ on the $380 \mathrm{~nm}$ thick YSZ thin film samples deposited on the nonporous polycrystalline alumina substrate and oxidized at $800^{\circ} \mathrm{C}$ for $5 \mathrm{hrs}$. The electrochemical impedance spectra were fitted using Z-view software based on nonlinear least square method and the equivalent circuit. Both bulk conductivity $\left(R_{\mathrm{e}}\right)$ and grain boundary conductivity $\left(R_{\mathrm{gb}}\right)$ were retrieved from the fitted results. Conductivity at each temperature point was then calculated from the total electrolyte resistance $\left(R_{\mathrm{e}}=R_{\mathrm{b}}+R_{\mathrm{gb}}\right)$. It is noteworthy that upon increasing temperature, the grain and grain boundary arcs overlap more significantly and hence rather difficult to separate. At temperature above $500^{\circ} \mathrm{C}$, we used the overall resistance directly without separation of grain and grain boundary part.

The Y/Zr film deposited on the nonporous alumina plate was subjected to in situ conductivity analyses in air upon 


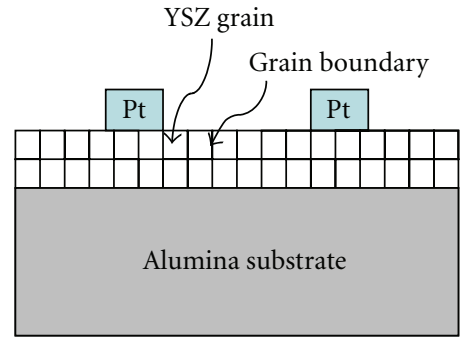

(a)

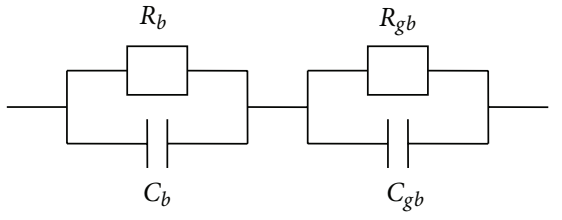

(b)

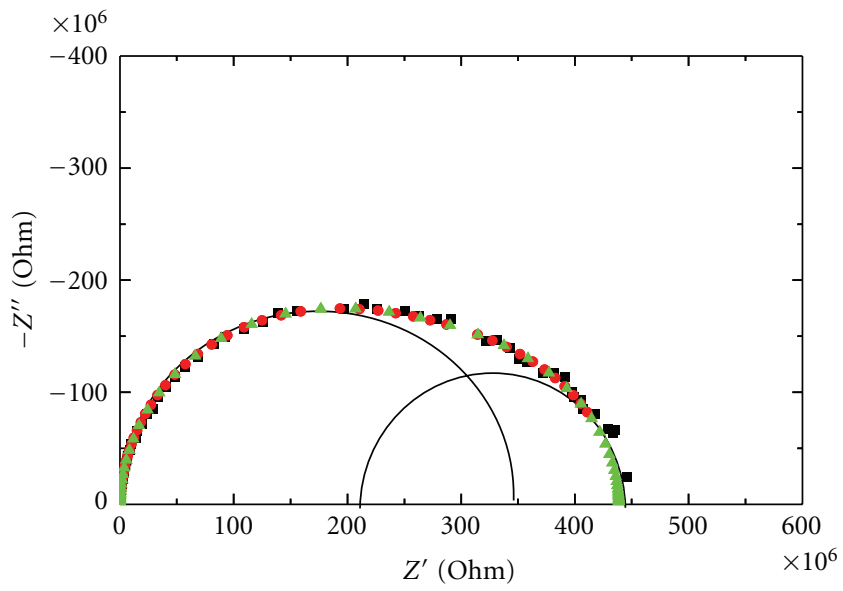

- $350^{\circ} \mathrm{C}$ data

- $2 \mathrm{RQ}$ fitting

- 2RQ simulation

(c)

Figure 4: (a) Schematics of the specimen for conductivity measurement. (b) Equivalent circuit corresponding bulk and grain boundary conductions in polycrystalline ionic conductors. Q: constant phase element. (c) Typical Nyquist plot recorded at $350^{\circ} \mathrm{C}$ on $380 \mathrm{~nm}$ thick YSZ thin film specimen after being oxidized at $800^{\circ} \mathrm{C}$ for $5 \mathrm{hrs}$.

increasing temperature. The logarithmic conductivities as a function of thermal oxidation temperatures are shown in Figure 5(a). To reach thermal equilibrium, electrochemical impedance spectra were recorded after 2 hours at each setting temperature. The EIS data were in situ collected in the temperature range between $50^{\circ} \mathrm{C}$ and $700^{\circ} \mathrm{C}$. The results showed that below $250^{\circ} \mathrm{C}$, the conductivities were in the range of $10^{3}-10^{4} \mathrm{~S} / \mathrm{cm}$ and then slightly decreased upon increasing temperature. The activation energy value was calculated, based on Nernst equation, less than $0.01 \mathrm{eV}$. This low activation energy and high conductivities suggested dominant electronic conduction in $\mathrm{Y} / \mathrm{Zr}$ films. Essentially, no oxidation of the Y/Zr films occurred at temperatures below $250^{\circ} \mathrm{C}$. As the oxidizing temperature was increased to $260^{\circ} \mathrm{C}$, conductivity values decreased significantly. At oxidizing temperature of $270^{\circ} \mathrm{C}$, the conductivity dropped off even more dramatically to $10^{-5} \mathrm{~S} / \mathrm{cm}$. This observation suggested that oxidation of $\mathrm{Y} / \mathrm{Zr}$ to $\mathrm{YSZ}$ began at the temperatures around $260-270^{\circ} \mathrm{C}$. However, $270^{\circ} \mathrm{C}$ was insufficient to completely oxidize the interior sections of the $\mathrm{Y} / \mathrm{Zr}$ films because of the slow oxygen diffusion. In the range from $270^{\circ} \mathrm{C}$ to $300^{\circ} \mathrm{C}$, decrease of conductivities continued. Electronic percolation paths were disconnected due to the increase of the oxide phase, leading to dramatic conductivity decrease. Increasing temperatures beyond $350^{\circ} \mathrm{C}$ resulted in a gradual increase in conductivities. Activation energy of the conductivity in the temperature range of $400-700^{\circ} \mathrm{C}$ was $1.06 \mathrm{eV}$. Ex situ XRD analyses confirmed fluoride structure of the thin films after oxidation at $400^{\circ} \mathrm{C}$.

To ensure fully oxidized and elimination of electronic contribution, the Ex situ conductivity analyses were performed on YSZ thin films after oxidization at $800^{\circ} \mathrm{C}$ and $1200^{\circ} \mathrm{C}$ for 5 hrs, as shown in Figure 5(b). The conductivities as well as activation energies of the YSZ thin films were compared with the reference $8 \%$ YSZ electrolyte plate purchased from the Japanese Fine Ceramics, as well as previously reported values associated with ionic conductivity of $8 \%$ YSZ $[7-9,18-21]$. The ionic conductivities of YSZ thin film oxidized at $1200^{\circ} \mathrm{C}$ were close to the reference data, while the values from YSZ thin film oxidized at $800^{\circ} \mathrm{C}$ were relatively lower. The slight difference in conductivities was probably associated with the $\mathrm{Y}$ and $\mathrm{Zr}$ distribution variation in the oxide films. High annealing temperatures like $1200^{\circ} \mathrm{C}$ allow sufficient $\mathrm{Y}$ diffusion across the thin film leading to a better compositional homogeneity. 


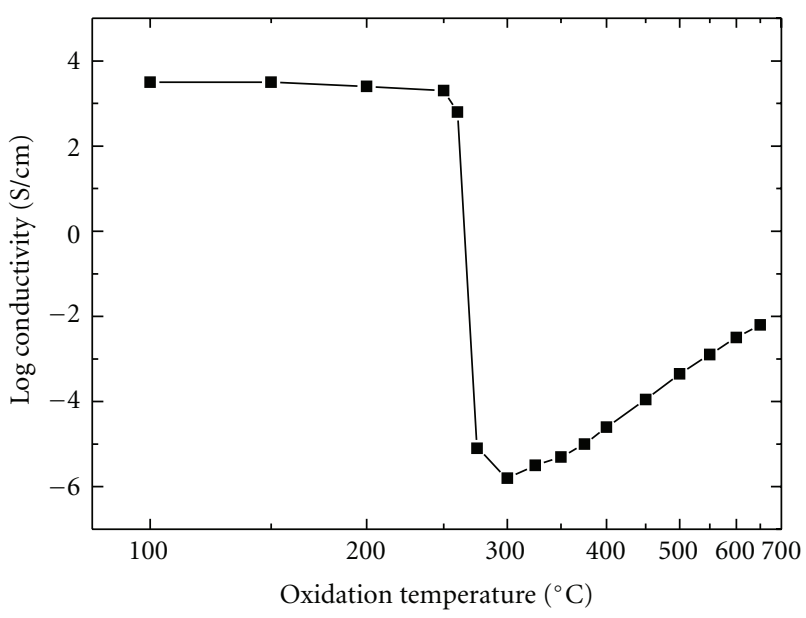

(a)

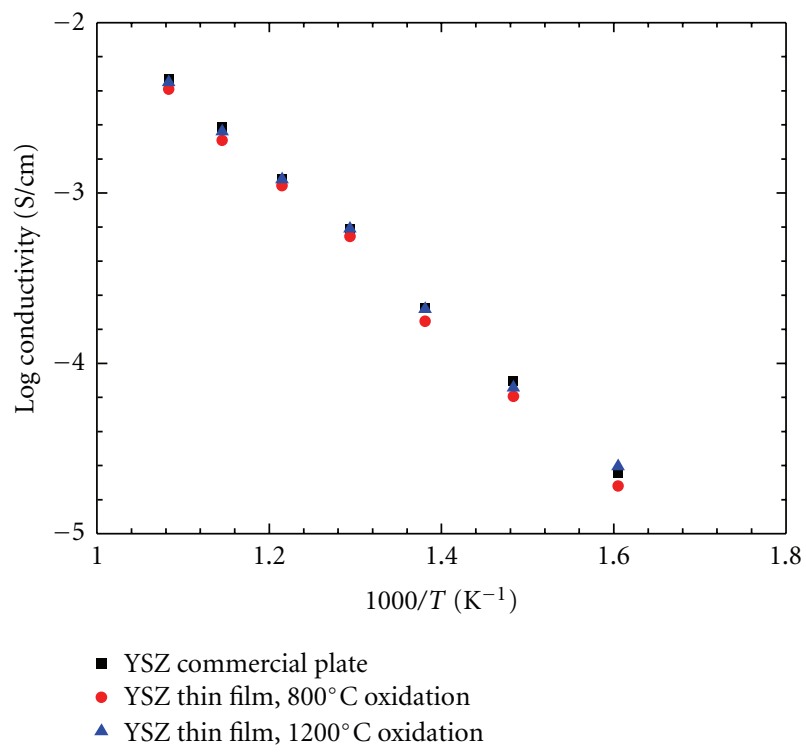

(b)

Figure 5: (a). In situ conductivities in logarithmic scale changes with thermal oxidation temperature. (b) Logarithmic conductivities versus reciprocal temperatures from YSZ thin films achieved at different oxidation temperatures, that are $800^{\circ} \mathrm{C}$ and $1200^{\circ} \mathrm{C}$, in comparison with $8 \mathrm{YSZ}$ commercial plate.

\section{Summary}

YSZ thin films were prepared on three substrates with different morphologies via DC-sputtering followed by thermal oxidation. Porous anodized alumina substrates result in sub-microthick films with nanopinholes, rendering unacceptable gas leakage for micro-SOFCs. Thermal oxidation will cause significant volume expansion. In consideration of this impact, pinhole/crack-free YSZ thin films can be achieved by appropriately controlling the porosity of the initial as-deposited Y/Zr films. The thin films exhibited fully ionic conduction after oxidation at high temperatures, for example, $800^{\circ} \mathrm{C}$ and $1200^{\circ} \mathrm{C}$, with ionic conductivities and activation energy values well corroborated with commercial
YSZ plates. The sub-microthin YSZ films deposited on Si wafer (with silicon nitride passivation layer) by DC magnetron-sputtering can potentially be utilized in thin-film and micro-SOFCs for intermediate temperature operations.

\section{Acknowledgment}

The author would like to thank Professor F. B. Prinz at the Department of Mechanical Engineering, Stanford University. Part of this research was conducted at his laboratory.

\section{References}

[1] S. C. Singhal, "Advances in solid oxide fuel cell technology," Solid State Ionics, vol. 135, no. 1-4, pp. 305-313, 2000.

[2] S. M. Haile, "Fuel cell materials and components," Acta Materialia, vol. 51, no. 19, pp. 5981-6000, 2003.

[3] B. C. H. Steele and A. Heinzel, "Materials for fuel-cell technologies," Nature, vol. 414, no. 6861, pp. 345-352, 2001.

[4] N. P. Brandon, S. Skinner, and B. C. H. Steele, "Recent advances in materials for fuel cells," Annual Review of Materials Research, vol. 33, pp. 183-213, 2003.

[5] X. Chen, N. J. Wu, L. Smith, and A. Ignatiev, "Thin-film heterostructure solid oxide fuel cells," Applied Physics Letters, vol. 84, no. 14, pp. 2700-2702, 2004.

[6] S. De Souza, S. J. Visco, and L. C. De Jonghe, "Thin-film solid oxide fuel cell with high performance at low-temperature," Solid State Ionics, vol. 98, no. 1-2, pp. 57-61, 1997.

[7] H. Huang, M. Nakamura, P. Su, R. Fasching, Y. Saito, and F. B. Prinz, "High-performance ultrathin solid oxide fuel cells for low-temperature operation," Journal of the Electrochemical Society, vol. 154, no. 1, pp. B20-B24, 2007.

[8] J. H. Shim, C. C. Chao, H. Huango, and F. B. Prinz, "Atomic layer deposition of yttria-stabilized zirconia for solid oxide fuel cells," Chemistry of Materials, vol. 19, no. 15, pp. 3850-3854, 2007.

[9] P. C. Su, C. C. Chao, J. H. Shim, R. Fasching, and F. B. Prinz, "Solid oxide fuel cell with corrugated thin film electrolyte," Nano Letters, vol. 8, no. 8, pp. 2289-2292, 2008.

[10] M. Gaudon, N. H. Menzler, E. Djurado, and H. P. Buchkremer, "YSZ electrolyte of anode-supported SOFCs prepared from sub micron YSZ powders," Journal of Materials Science, vol. 40, no. 14, pp. 3735-3743, 2005.

[11] L. Zhang, S. P. Jiang, W. Wang, and Y. Zhang, "NiO/YSZ, anode-supported, thin-electrolyte, solid oxide fuel cells fabricated by gel casting," Journal of Power Sources, vol. 170, no. 1, pp. 55-60, 2007.

[12] D. Beckel, A. Bieberle-Hütter, A. Harvey et al., "Thin films for micro solid oxide fuel cells," Journal of Power Sources, vol. 173, no. 1, pp. 325-345, 2007.

[13] A. Infortuna, A. S. Harvey, and L. J. Gauckler, "Microstructures of CGO and YSZ thin films by pulsed laser deposition," Advanced Functional Materials, vol. 18, no. 1, pp. 127-135, 2008.

[14] M. Ohring, Materials Science of Thin Films, Academic Press, London, UK, 2nd edition, 2002.

[15] Y. I. Park, P. C. Su, S. W. Cha, Y. Saito, and F. B. Prinz, “Thinfilm SOFCs using gastight YSZ thin films on nanoporous substrates," Journal of the Electrochemical Society, vol. 153, no. 2, pp. A431-A436, 2006.

[16] H. Huang, T. M. Gür, Y. Saito, and F. Prinz, "High ionic conductivity in ultrathin nanocrystalline gadolinia-doped 
ceria films," Applied Physics Letters, vol. 89, no. 14, Article ID 143107, 2006

[17] E. Baroukov and J. R. Macdonald, Impedance Spectroscopy: Theory, Experiment, and Applications, John Wiley \& Sons, Hoboken, NJ, USA, 2nd edition, 2005.

[18] S. P. S. Badwal, "Electrical conductivity of single crystal and polycrystalline yttria-stabilized zirconia," Journal of Materials Science, vol. 19, no. 6, pp. 1767-1776, 1984.

[19] J. Van Herle, A. J. McEvoy, and K. R. Thampi, "Conductivity measurements of various yttria-stabilized zirconia samples," Journal of Materials Science, vol. 29, no. 14, pp. 3691-3701, 1994.

[20] M. C. Steil, F. Thevenot, and M. Kleitz, "Densification of yttria-stabilized zirconia: Impedance spectroscopy analysis," Journal of the Electrochemical Society, vol. 144, no. 1, pp. 390398, 1997.

[21] M. Hattori, Y. Takeda, Y. Sakaki et al., "Effect of aging on conductivity of yttria stabilized zirconia," Journal of Power Sources, vol. 126, no. 1-2, pp. 23-27, 2004. 


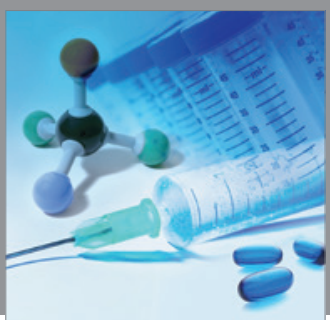

International Journal of

Medicinal Chemistry

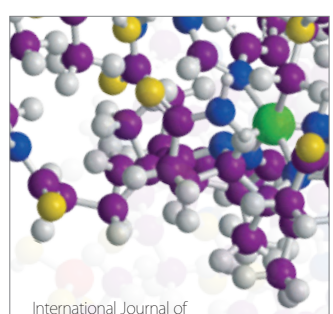

Carbohydrate Chemistry

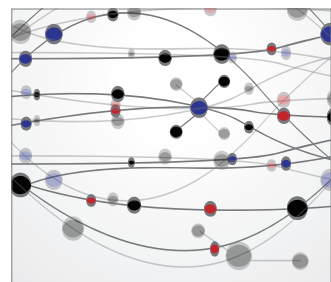

The Scientific World Journal
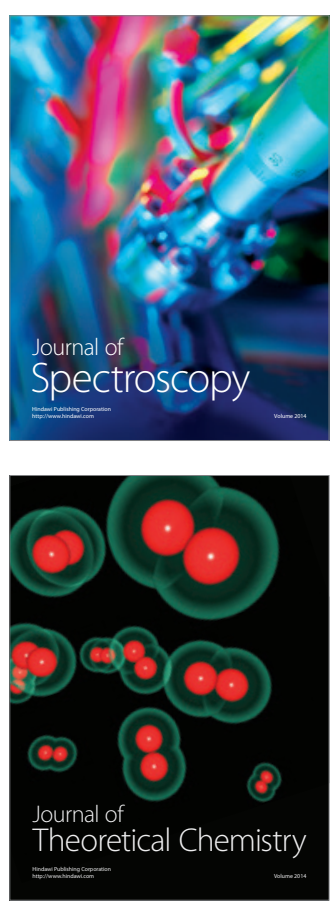
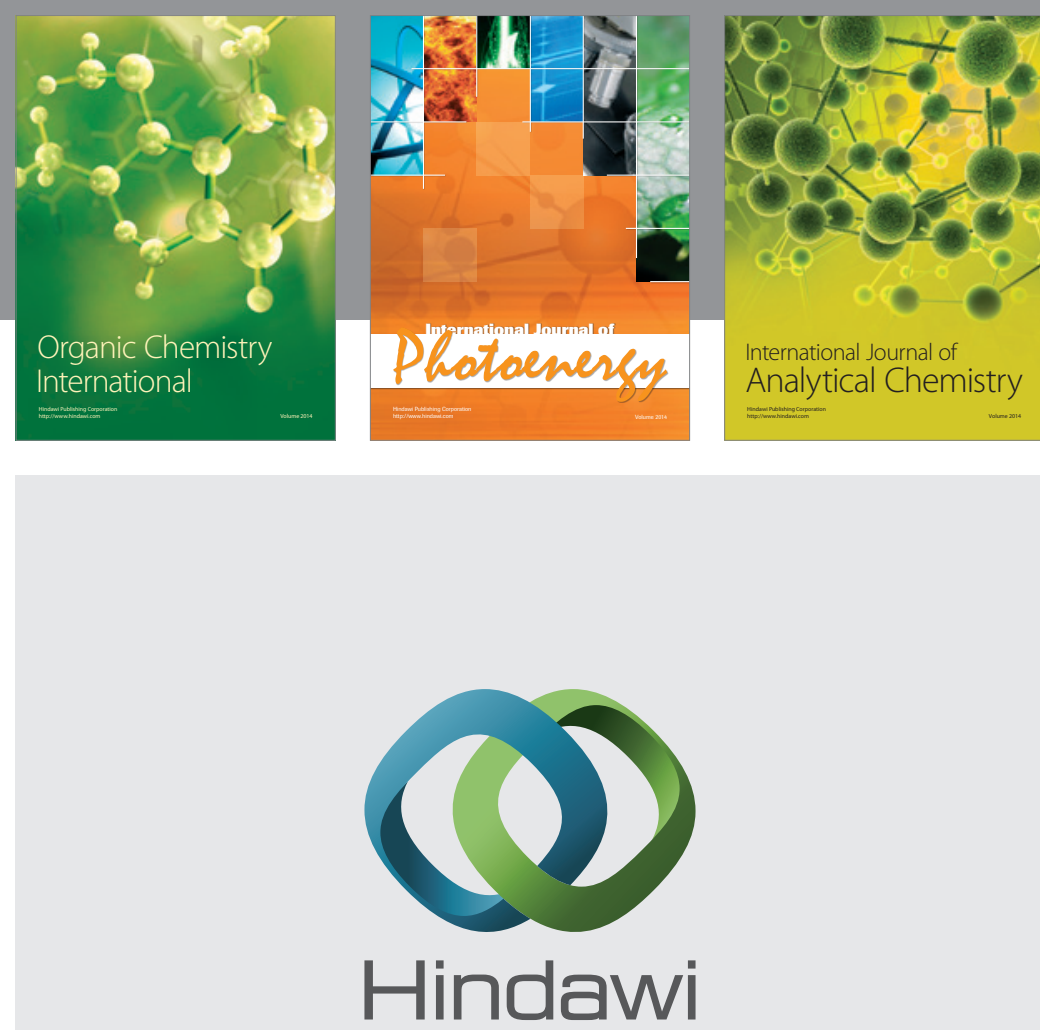

Submit your manuscripts at

http://www.hindawi.com
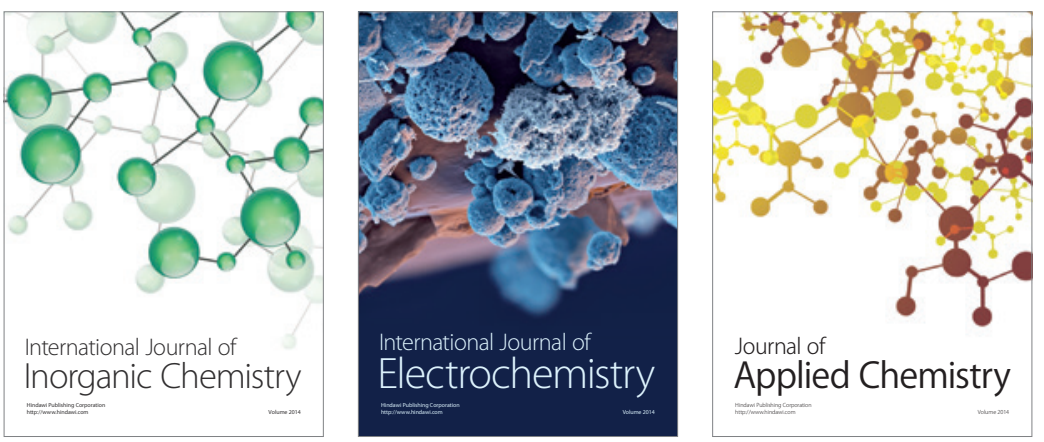

Journal of

Applied Chemistry
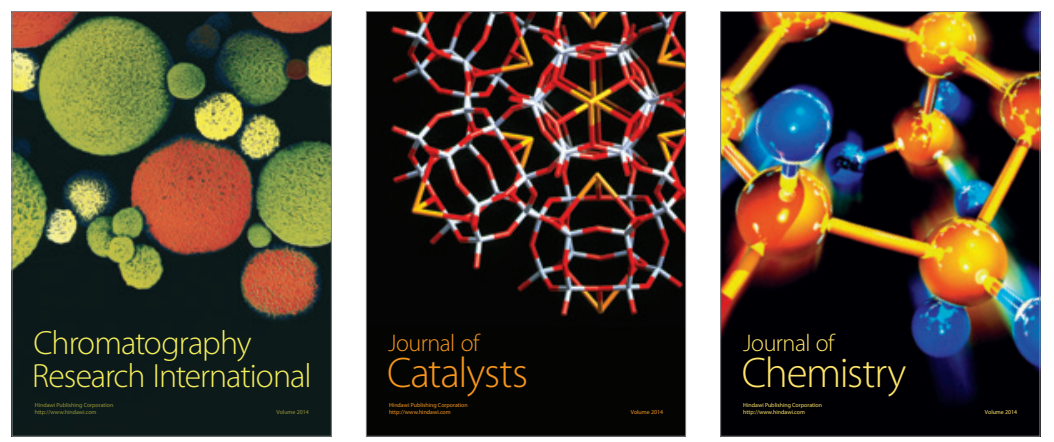
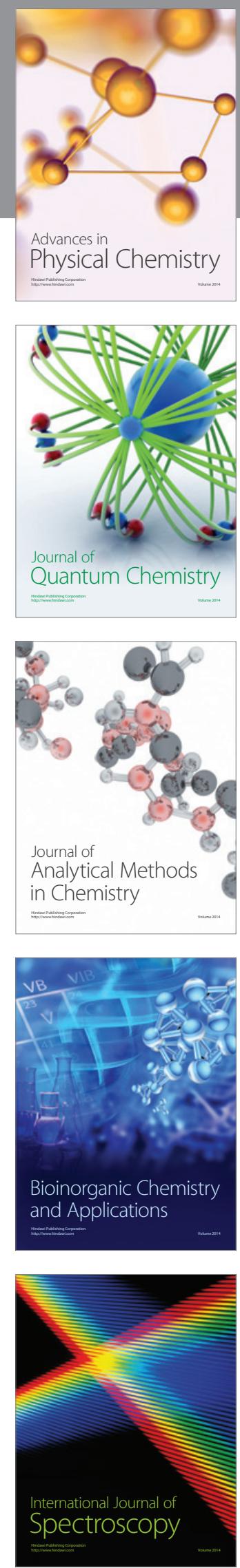